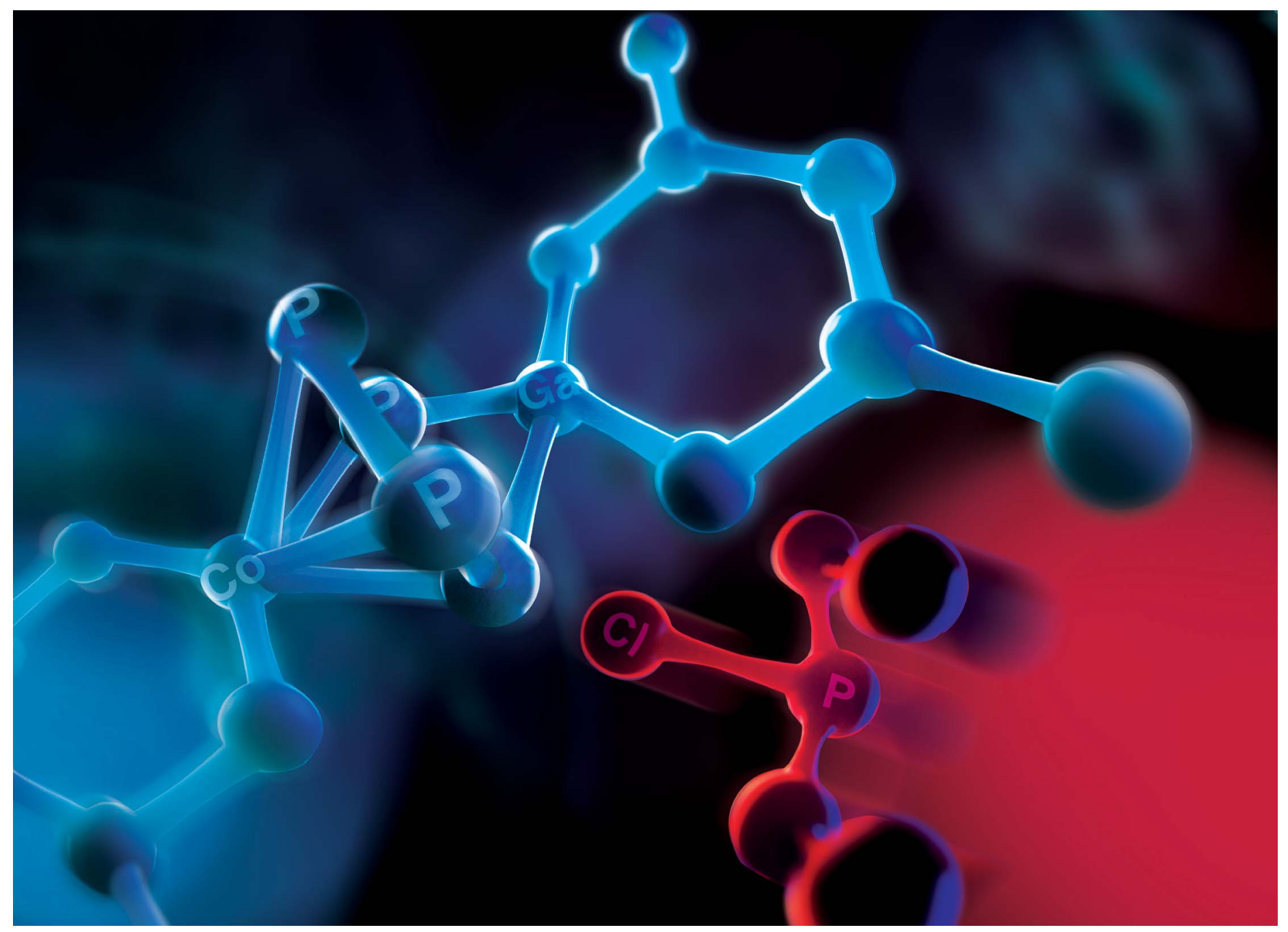

Showcasing research from the laboratories of Prof. Robert Wolf (University of Regensburg, Germany) and Prof. Jan J. Weigand (Technical University of Dresden, Germany).

Construction of alkyl-substituted pentaphosphido ligands in the coordination sphere of cobalt

P-P condensations afford unusual diorganopentaphospido ligands in cobalt complexes. These new species were obtained by reacting a tetraphosphido cobalt-gallium compound (accessible in two steps from white phosphorus) with chlorophosphanes. This work presents a proof-of-principle for the use of heterobimetallic complexes as precursors for the targeted construction of novel substituted polyphosphorus frameworks.

\section{As featured in:}

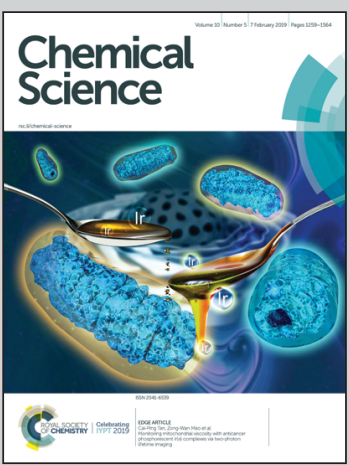

See Jan J. Weigand,

Robert Wolf et al.,

Chem. Sci., 2019, 10, 1302. 
Check for updates

Cite this: Chem. Sci., 2019, 10, 1302

๑ All publication charges for this article have been paid for by the Royal Society of Chemistry

Received 24th October 2018

Accepted 29th November 2018

DOI: $10.1039 / \mathrm{c} 8 \mathrm{sc} 04745 f$

rsc.li/chemical-science

\title{
Construction of alkyl-substituted pentaphosphido ligands in the coordination sphere of cobalt $\uparrow$
}

\author{
Christoph G. P. Ziegler, (D) a Thomas M. Maier, (D) ${ }^{a}$ Stefan Pelties, ${ }^{a}$ Clemens Taube, ${ }^{b}$ \\ Felix Hennersdorf, $\mathbb{D}^{\mathrm{b}}{ }^{\mathrm{b}}$ Andreas W. Ehlers, ${ }^{\mathrm{cd}}$ Jan J. Weigand $\left(\mathbb{D}\right.$ *b and Robert Wolf $\mathbb{D}^{*}$ *a
}

Rare mono- and diorganopentaphosphido cobalt complexes are accessible by $\mathrm{P}-\mathrm{P}$ condensation using the unprecedented, reactive cobalt-gallium tetraphosphido complex $\left[K(d m e)_{2}\left\{\left({ }^{M e s} B \mid A N\right) C o\left(\mu-\eta^{4}: \eta^{2}-P_{4}\right)\right.\right.$ $\mathrm{Ga}($ nacnac) $\}]$ (2). Compound 2 was prepared in good yield by reaction of $\left[K\left(\mathrm{Et}_{2} \mathrm{O}\right)\left\{\left({ }^{\mathrm{Mes}} \mathrm{BIAN}\right) \mathrm{Co}\left(\eta^{4}-1,5-\right.\right.\right.$ cod)\}] [1, BIAN = bis(mesitylimino)acenaphthene diimine, $\operatorname{cod}=1,5$-cyclooctadiene $]$ with $\left[\mathrm{Ga}\left(\right.\right.$ nacnac) $\left.\left(\eta^{2}-\mathrm{P}_{4}\right)\right]$ (nacnac $\left.=\mathrm{CH}\left[\mathrm{CMeN}\left(2,6-\mathrm{Pr}_{2} \mathrm{C}_{6} \mathrm{H}_{3}\right)\right]_{2}\right)$. Reactions with $\mathrm{R}_{2} \mathrm{PCl}(\mathrm{R}=\mathrm{iPr}$, $t \mathrm{Bu}$, and $\mathrm{Cy})$ selectively afford $\left[\left({ }^{\text {Mes } B I A N) C o(c y c l o-} P_{5} R_{2}\right)\right] \quad(3 a-c)$, which feature $\eta^{4}$-coordinated 1,1diorganopentaphosphido ligands. The mechanism of formation of these species has been studied by ${ }^{31} \mathrm{P}\left\{{ }^{1} H\right\}$ NMR spectroscopy and DFT calculations. In the case of $3 a(R=i \operatorname{Pr})$, it was possible to identify the intermediate [( $\left.{ }^{\text {Mes }} \mathrm{BIAN}\right) \mathrm{Co}\left(\mu-\eta^{4}: \eta^{2}-\mathrm{P}_{5} \mathrm{iPr} 2\right) \mathrm{Ga}($ nacnac) $]$ (4) by single-crystal X-ray diffraction. A related, monosubstituted organopentaphosphido cobalt complex [( $\left.\left.{ }^{\text {Mes }} \mathrm{BIAN}\right) \mathrm{Co}\left(\mu-\eta^{4}: \eta^{1}-\mathrm{P}_{5} \mathrm{tBu}\right) \mathrm{GaCl}(\mathrm{nacnac})\right]$ (5) was isolated by reacting dichloroalkylphosphane $t \mathrm{BuPCl}_{2}$ with 2 . Heterobimetallic complexes such as 2 thus may enable the targeted construction of a range of new metal-coordinated polyphosphorus frameworks by P-P condensation.

\section{Introduction}

Over the past decades, much effort has been invested into the synthesis of transition metal polyphosphido complexes. ${ }^{\mathbf{1 , 2}}$ An impressive and structurally diverse array of early and late transition metal polyphosphorus species has become accessible. Most commonly, such species have been prepared by reaction of low-valent transition metal precursors with white phosphorus. While the functionalization of the polyphosphorus units derived from $\mathrm{P}_{4}$ and in particular the construction of new polyphosphorus ligands, is an attractive target, successful examples of such transformations are surprisingly scarce. This paucity is largely due to the sluggish reactivity of known complexes with electrophiles such as halophosphanes. Seminal reports by Cummins and co-workers have demonstrated the synthetic potential of some early polyphosphido transition

${ }^{a}$ University of Regensburg, Institute of Inorganic Chemistry, 93040 Regensburg, Germany. E-mail: robert.wolf@ur.de

${ }^{b} T U$ Dresden, Faculty of Chemistry and Food Chemistry, 01062 Dresden, Germany. E-mail: jan.weigand@tu-dresden.de

'University of Amsterdam, Faculty of Science, van't Hoff Institute for Molecular Sciences, Science Park 904, 1090 GS Amsterdam, The Netherlands

${ }^{d}$ University of Johannesburg, Department of Chemistry, Auckland Park, Johannesburg, 2006, South Africa

$\dagger$ Dedicated to Professor Dietmar Stalke on the occasion of his 60th birthday.

\$ Electronic supplementary information (ESI) available. CCDC 1861829-1861837 and 1874059. For ESI and crystallographic data in CIF or other electronic format see DOI: $10.1039 / \mathrm{c} 8 \mathrm{sc} 04745 \mathrm{f}$ metalate anions. ${ }^{2-4}$ The $\left[\mathrm{Nb}(\mathrm{OAr})_{3}\left(\eta^{3}-\mathrm{P}_{3}\right)\right]^{-}$anion $(\mathbf{A}, \mathrm{Ar}=2,6-$ $\mathrm{iPr}_{2} \mathrm{C}_{6} \mathrm{H}_{3}$ ) was used for generating a coordinated diphosphorus molecule in situ under mild conditions to access diphosphanes (Scheme 1a). ${ }^{5}$ Cummins and co-workers also devised a synthetic cycle to yield useful phosphaalkynes, and they have been using their niobium phosphido complexes to access several further unprecedented $\mathrm{P}$ compounds, including the previously unknown $\mathrm{AsP}_{3}$ molecule obtained by reacting $\mathbf{A}$ with arsenic trichloride..$^{3,4,6,7}$

While these results indicate that anionic polyphosphido complexes are attractive precursors for functionalisation reactions, there have only been scattered examples with other metals. ${ }^{8-11}$ Peruzzini and Stoppioni reported the alkylation and hydrolysis of group 8 and 9 complexes, for example using ruthenium phosphido compounds (Scheme 1b). ${ }^{8}$ Moreover, Scheer described the functionalization of cyclo- $\mathrm{P}_{5}$ and cyclo- $\mathrm{P}_{3}$ units in iron and nickel complexes by main group element nucleophiles such as amides, phosphanides, and hydrocarbyl anions (Scheme 1c). ${ }^{9,10}$ The same group recently reported the synthesis of the first triarsa- and the triphosphatrisilabenzenes by a successful metathesis reaction of a tetraphosphido zirconium complex with a chlorosilylene. ${ }^{\mathbf{1 1}}$

Here, we describe a new strategy for the synthesis of unprecedented polyphosphido complexes, which uses heterobimetallic complexes derived from $\mathrm{P}_{4}$ as a tool for the construction of more extended $\mathrm{P}_{n}$ units. As a proof of principle, we have synthesized the new $\mathrm{CoGaP}_{4}$ complex $\left[\mathrm{K}(\mathrm{dme})_{2}\right.$ $\left\{\left({ }^{\text {Mes }}\right.\right.$ BIAN $) \mathrm{Co}\left(\mu-\eta^{4}: \eta^{2}-\mathrm{P}_{4}\right) \mathrm{Ga}($ nacnac $\left.\left.)\right\}\right] \quad\left(2, \quad{ }^{\text {Mes }}\right.$ BIAN $=1,2-$ 
a) Cummins 2006 - 2012

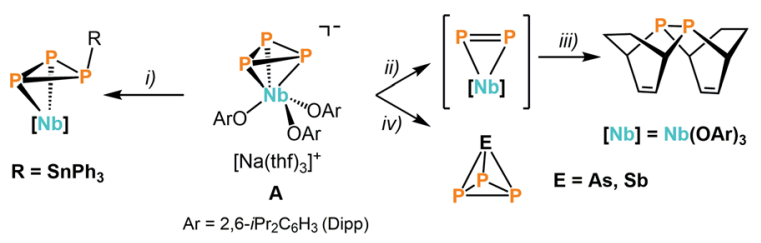

b) Peruzzini, Stoppioni 2012

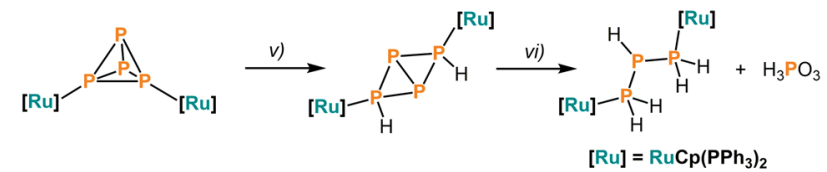

c) Scheer 2013, 2014
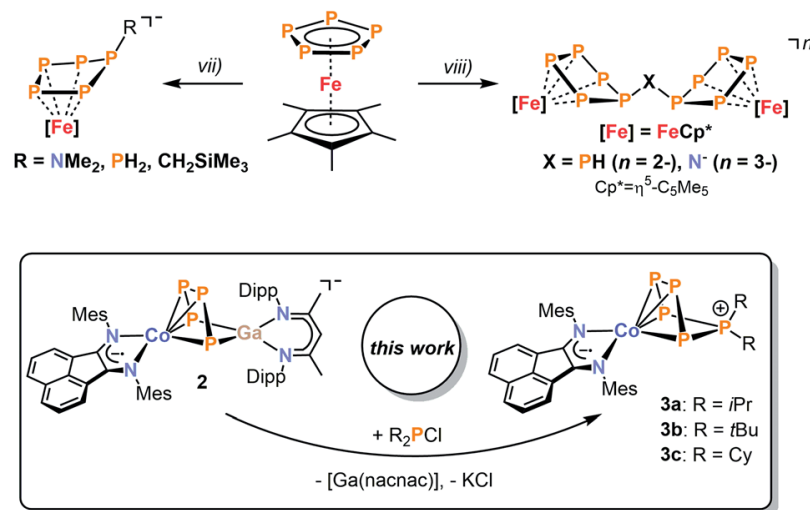

Scheme 1 Functionalization of activated phosphorus units; reagents and products: (i) $+\mathrm{Ph}_{3} \mathrm{SnCl}-\mathrm{NaCl}$; (ii) + IMo(N[tBu]Ar) ${ }_{3} /-\mathrm{Nal},-\mathrm{PMo}(\mathrm{N}$ $\left\{\right.$ tBu\}Ar) 3 ; (iii) +1,3-cyclohexadiene, $+\mathrm{C}_{5} \mathrm{H}_{5} \mathrm{NO} /-\mathrm{C}_{5} \mathrm{H}_{5} \mathrm{~N},-([\mathrm{Nb}] \mathrm{O})_{2}$; (iv) $+\mathrm{ECl}_{3} /-\mathrm{NaCl},-[\mathrm{Nb}] \mathrm{Cl}_{2} ;$ (v) $+\mathrm{I}_{2},+\mathrm{H}_{2} \mathrm{O}$, +NaOTf; (vi) $+\mathrm{H}_{2} \mathrm{O}$; (vii) $+\mathrm{LiCH}_{2} \mathrm{SiMe}_{3}$ or $+\mathrm{LiNMe}_{2}$ or $+\mathrm{LiPH}_{2}$; (viii) $+\mathrm{NaNH}_{2}$; $+\mathrm{LiPH}_{2}$. (top). Functionalization of anionic heterodinuclear tetraphosphido complexes by P-P condensation (bottom).

bis(2,4,6-dimethylphenylimino)acenaphthene, nacnac $=\mathrm{CH}$ $\left.\left[\mathrm{CMeN}\left(2,6-\mathrm{iPr}_{2} \mathrm{C}_{6} \mathrm{H}_{3}\right)\right]_{2}\right)$. This complex is a useful precursor for the targeted synthesis of the first diorganopentaphosphido complexes $\left[\left({ }^{\mathrm{Mes}} \mathrm{BIAN}\right) \mathrm{Co}\left(\right.\right.$ cyclo $\left.\left.-\mathrm{P}_{5} \mathrm{R}_{2}\right)\right](3 \mathrm{a}, \mathrm{R}=\mathrm{iPr} ; 3 \mathbf{b}, \mathrm{R}=t \mathrm{Bu} ; 3 \mathbf{c}$, $\mathrm{R}=\mathrm{Cy}) \cdot{ }^{31} \mathrm{P}$ NMR monitoring and the structural characterization of a presumed intermediate $\left[\left({ }^{\mathrm{Mes}} \mathrm{BIAN}\right) \operatorname{Co}\left(\mu-\eta^{4}: \eta^{2}-\mathrm{P}_{5} \mathrm{iPr}_{2}\right)\right.$ $\mathrm{Ga}($ nacnac)] (4) shed light on the reaction mechanism. Moreover, we report the synthesis of $\left[\left({ }^{\mathrm{Mes}} \mathrm{BIAN}\right) \mathrm{Co}\left(\mu-\eta^{4}: \eta^{1}-\mathrm{P}_{5} t \mathrm{Bu}\right) \mathrm{GaCl}\right.$ (nacnac)] (5). The molecular structure of 5 is unusual in that it contains a disubstituted $\mathrm{P}_{5}$ ligand with a single $t$ Bu moiety and a gallyl-substituent $\mathrm{GaCl}($ nacnac).

\section{Results}

Reaction of $\left[\mathrm{K}\left(\mathrm{Et}_{2} \mathrm{O}\right)\left\{\left({ }^{\mathrm{Mes}} \mathrm{BIAN}\right) \mathrm{Co}\left(\eta^{4}-1,5-\mathrm{cod}\right)\right\}\right] \quad(\mathbf{1})^{\mathbf{1 2 , 1 3}}$ with $\left[(\right.$ nacnac $\left.) \mathrm{Ga}\left(\eta^{2}-\mathrm{P}_{4}\right)\right]$, obtained from white phosphorus and [Ga(nacnac)] according to a literature procedure, ${ }^{\mathbf{1 4}}$ in $\mathrm{THF}$ affords the heterodinuclear complex 2 (Scheme 2). ${ }^{31} \mathrm{P}\left\{{ }^{1} \mathrm{H}\right\}$ NMR monitoring indicates that the reaction is very selective and affords 2 as the sole P-containing product. After work-up, 2 was isolated in $59 \%$ yield by crystallization from $\mathrm{DME} / n$-hexane. It is noteworthy that the 2,6-diisopropylphenyl-substituted complex $\left[\mathrm{K}(\text { thf })_{2}\left\{\left({ }^{\mathrm{Dipp}} \mathrm{BIAN}\right) \mathrm{Co}\left(\mu-\eta^{4}: \eta^{2}-\mathrm{P}_{4}\right) \mathrm{Ga}(\right.\right.$ nacnac $\left.\left.)\right\}\right] \quad\left(2^{\prime}\right)$ can be

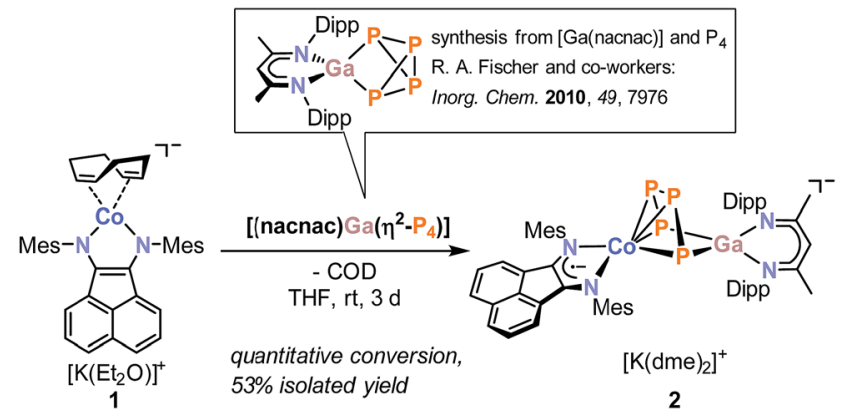

Scheme 2 Synthesis of $\left[K(d m e)_{2}\left\{\left(\left(^{\text {Mes }} B I A N\right) C o\left(\mu-\eta^{4}: \eta^{2}-P_{4}\right) G a\right.\right.\right.$ (nacnac)\}] (2).

synthesized and isolated in an analogous manner in 53\% yield by recrystallization from $\mathrm{THF} / n$-hexane. ${ }^{13}$ Both complexes are very similar, therefore subsequent reactivity studies focused exclusively on the Mes-substituted complex 2. The molecular structure of 2 (Fig. 1) shows a chain of four $\mathrm{P}$ atoms sandwiched between cobalt and gallium. The terminal $\mathrm{P}-\mathrm{P}$ bonds $(\mathrm{P} 1-\mathrm{P} 2=$

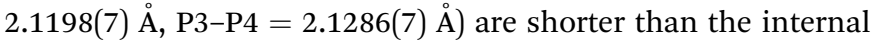
$\mathrm{P}-\mathrm{P}$ bond $(\mathrm{P} 2-\mathrm{P} 3=2.1755(8) \AA)$ and the distance between the terminal $\mathrm{P}$ atoms (P1-P4 = 3.3073(6) $\AA$ ) is large. The dihedral angle $\mathrm{P} 1, \mathrm{P} 2, \mathrm{P} 3, \mathrm{P} 4$ with a value of $1.3^{\circ}$ indicates that the $\mathrm{P}_{4}$ chain is nearly planar. The $\mathrm{C}-\mathrm{C}$ and $\mathrm{C}-\mathrm{N}$ bond distances of the BIAN moiety suggests that it is present in its radical anionic form. ${ }^{12}$ The coordination sphere of the potassium cation contains two DME molecules and two $\mathrm{P}$ atoms of the $\mathrm{P}_{4}$ chain

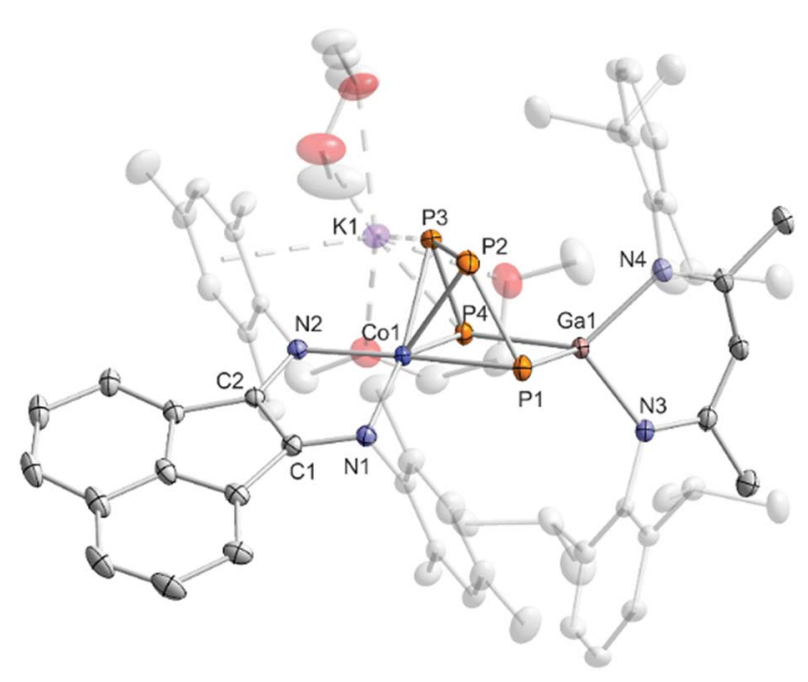

Fig. 1 Solid-state molecular structure of $\left[K(\mathrm{dme})_{2}\left\{\left({ }^{\mathrm{Mes}} \mathrm{BIAN}\right)\right.\right.$ $\mathrm{Co}\left(\mu-\eta^{4}: \eta^{2}-\mathrm{P}_{4}\right) \mathrm{Ga}($ nacnac) $\left.\}\right]$ (2) hydrogen atoms are omitted for clarity and thermal ellipsoids are drawn at the $40 \%$ probability level; selected bond lengths $[\AA \AA]$ and angles $\left[{ }^{\circ}\right]$ : P1-P2 2.1198(7), P2-P3 2.1755(8), P3P4 2.1286(7), P1 ...P4 = 3.3073(6), P4-Ga1 2.3328(5), P1-Ga1 2.3179(5), Ga1-N3 1.991(1), Ga1-N4 2.014(2), Co1-P1 2.3514(6), Co1-P2 2.3098(6), Co1-P3 2.3117(5), Co1-P4 2.3961(6), Co1-N1 1.918(2), Co1-N2 1.948(2), N1-C1 1.337(2), N2-C2 1.334(2), C1-C2 1.411(3), K1-P3 3.7168(7); K1-P4 3.33073(6), Ga1-P4-P3 94.85(2), P4-P3-P2 106.97(3), P3-P2-P1 103.92(3), P2-P1-Ga1 97.31(2), P1-Ga1-P4 $90.66(2)$; bond distances and angles of derivative $2^{\prime}$ are presented in the ESI (see Fig. S39, ESI $\$)^{13}$ 
$(\mathrm{K} 1-\mathrm{P} 4=3.3430(6) \AA, \mathrm{K} 1-\mathrm{P} 3=3.7168(7) \AA$, $c f$. the sum of the van-der-Waals radii of $\mathrm{K}$ and $\mathrm{P}: 4.63 \AA) .{ }^{15}$

A few transition metal complexes with structures related to 2 are known. For example, Scherer's dirhodium complex $\left[\left(C p^{\mathrm{R}} \mathrm{Rh}\right)\left(\mu-\eta^{4}: \eta^{2}-\mathrm{P}_{4}\right)\left\{\mathrm{Rh}(\mathrm{CO}) \mathrm{Cp}^{\mathrm{R}}\right\}\right]\left(\mathrm{Cp}^{\mathrm{R}}=\eta^{5}-\mathrm{C}_{5} \mathrm{Me}_{4} \mathrm{Et}\right)$ shows a very similar motif with a $\mathrm{P}_{4}$ chain $(\mathrm{P}-\mathrm{P} 2.150(3) \AA-2.160(3) \AA)$ coordinating to two rhodium centers in an $\eta^{2}$ - and an $\eta^{4}$ fashion, respectively. ${ }^{16}\left[\mathrm{LSi}\left(\mu-\eta^{2}: \eta^{2}-\mathrm{P}_{4}\right) \mathrm{Ni}(\right.$ nacnac $\left.)\right](\mathrm{L}=\mathrm{CH}[(\mathrm{C}=$ $\left.\left.\left.\mathrm{CH}_{2}\right) \mathrm{CMe}\right]\left[\mathrm{N}\left(2,6-\mathrm{Prr}_{2} \mathrm{C}_{6} \mathrm{H}_{3}\right)\right]_{2}\right)$, reported by Driess and coworkers, is also similar, but this complex features a more weakly activated, "butterfly"- $\mathrm{P}_{4}$ ligand $(\mathrm{P} 1-\mathrm{P} 4=2.335(4) \AA) .{ }^{17}$ Roesky, Konchenko, Scheer, and co-workers synthesized $\left[\left(\mathrm{Cp}^{\prime \prime \prime} \mathrm{Co}\right)_{2}\left(\mu_{3}-\eta^{2}: \eta^{2}: \eta^{2}-\mathrm{P}_{4}\right) \mathrm{SmCp}_{2}\right]\left(\mathrm{Cp}^{*}=\eta^{5}-\mathrm{C}_{5} \mathrm{Me}_{5}, \mathrm{Cp}^{\prime \prime \prime}=\eta^{5}-\right.$ $\left.1,2,4-t \mathrm{Bu}_{3} \mathrm{C}_{5} \mathrm{H}_{2}\right)$ via an unusual intramolecular $\mathrm{P}-\mathrm{P}$ coupling process. ${ }^{18}$ The $\mathrm{P}_{4}$ chain observed in this trimetallic complex shows even somewhat longer P-P bonds (2.154(4) $\mathrm{A}-2.251(4) \AA)$ than 2. Further examples of transition metal complexes with bridging catena- $\mathrm{P}_{4}$ units are diiron species reported by Scherer, ${ }^{19}$ Miluykov, ${ }^{20}$ and Walter, ${ }^{21}$ as well as a dizirconium complex described by Fryzuk. ${ }^{22}$

In agreement with the solid-state structure, the ${ }^{31} \mathrm{P}\left\{{ }^{1} \mathrm{H}\right\} \mathrm{NMR}$ spectrum of 2 in THF- $d_{8}$ (Fig. 2 and S6, ESI spin systems. ${ }^{13}$ DFT calculations indicate that the multiplet at low frequency $(-125.4 \mathrm{ppm})$ can be assigned to the terminal $\mathrm{P}$ atoms $\left(\mathrm{P}_{\mathrm{xx}^{\prime}}\right)$, while the multiplet at high frequency can be assigned to the internal $\mathrm{P}$ atoms $\left(\mathrm{P}_{\mathrm{AA}^{\prime}}\right.$, see the ESIt for details $) .{ }^{13}$ Iterative fitting of the ${ }^{31} \mathrm{P}\left\{{ }^{1} \mathrm{H}\right\}$ NMR spectrum revealed a ${ }^{1} J_{\mathrm{AX}^{\prime}}$ coupling constant of $-450.5 \mathrm{~Hz}$, which is $70 \mathrm{~Hz}$ larger in magnitude than the ${ }^{1} J_{\mathrm{AA}}$ coupling constant $(-380.5 \mathrm{~Hz})$. The ${ }^{2} J_{\mathrm{AX}^{\prime}}(6.6 \mathrm{~Hz})$ and ${ }^{3} J_{\mathrm{XX}^{\prime}}(-7.2 \mathrm{~Hz})$ couplings are rather small which is in line with the constrained alignment of the $\mathrm{P}$ atoms in the $\mathrm{P}_{4}$ chain observed in the solid-state structure, causing an antiparallel orientation of the lone pairs. ${ }^{23}$

Initial reactivity studies of 2 focused on reactions with dialkylchlorophosphanes. ${ }^{31} \mathrm{P}\left\{{ }^{1} \mathrm{H}\right\}$ NMR monitoring of the reactions of 2 with $\mathrm{R}_{2} \mathrm{PCl}(\mathrm{R}=\mathrm{iPr}, t \mathrm{Bu}$, and $\mathrm{Cy}$ ) suggests the formation of pentaphosphido complexes [( $\left.{ }^{\mathrm{Mes}} \mathrm{BIAN}\right)$ $\left.\mathrm{Co}\left(\eta^{4}-\mathrm{P}_{5} \mathrm{R}_{2}\right)\right]$ (3a, $\mathrm{R}=\mathrm{iPr} ; \mathbf{3 b}, \mathrm{R}=t \mathrm{Bu} ; \mathbf{3} \mathbf{c}, \mathrm{R}=\mathrm{Cy}$, Scheme 3$)$.

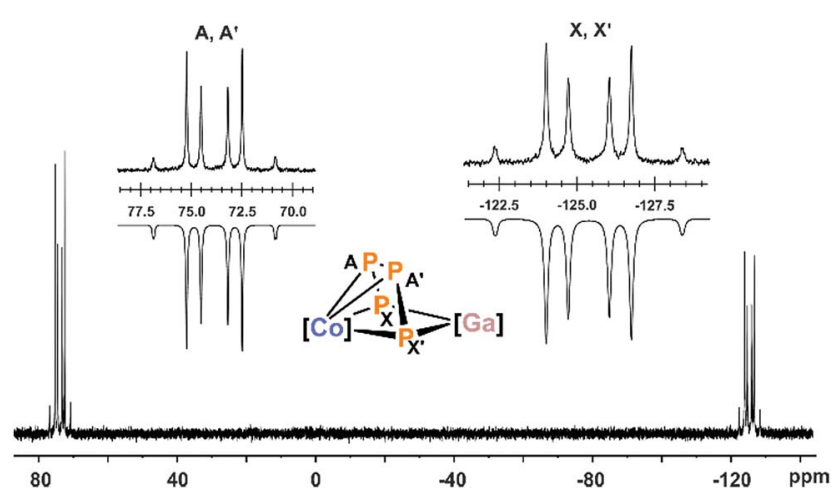

Fig. $2{ }^{31} \mathrm{P}\left\{{ }^{1} \mathrm{H}\right\}$ NMR spectrum of compound 2 with nuclei assigned to an $A A^{\prime} X X^{\prime}$ spin system; insets: extended signals (upwards) and simulations (downwards); $\delta\left(\mathrm{P}_{\mathrm{AA}^{\prime}}\right)=74.0 \mathrm{ppm}, \delta\left(\mathrm{P}_{\mathrm{XX}^{\prime}}\right)=-125.4 \mathrm{ppm},{ }^{1} \mathrm{~J}_{\mathrm{AA}^{\prime}}=$ ${ }^{1} J_{A^{\prime} A}=-380.5 \mathrm{~Hz},{ }^{1} J_{A X}={ }^{1} J_{A^{\prime} X^{\prime}}=-450.5 \mathrm{~Hz},{ }^{2} J_{A^{\prime}}={ }^{2} J_{A^{\prime} X}=6.6 \mathrm{~Hz}$, ${ }^{3} J_{X^{\prime}}={ }^{3} J_{X^{\prime} X}=-7.2 \mathrm{~Hz}$; the spectrum of $2^{\prime}$ is very similar (see Fig. S11 and S12, ESI $)^{13}[\mathrm{Co}]=\left({ }^{\text {Mes } B I A N) C o, ~[G a]}=(\right.$ nacnac $)$ Ga.
Chromatographic work-up is necessary to remove the byproduct $[\mathrm{Ga}($ nacnac) $]$. Recrystallization from $n$-hexane (3a and b) or $n$-hexane/toluene (3c) gave analytically pure, cyan-colored crystals of the products 3a-c in moderate yields (26\% to $31 \%$ ).

According to single-crystal XRD studies, compounds $\mathbf{3 a - c}$ are isostructural and feature an unprecedented $\eta^{4}$-coordinated cyclo- $\mathrm{P}_{5} \mathrm{R}_{2}$ ligand in an envelope conformation. Interestingly, 3a-c may be regarded as transition metal complexes of the corresponding $\left[\mathrm{P}_{5} \mathrm{R}_{2}\right]^{+}$cage cations, ${ }^{24-27}$ but in fact they show structural isomers of these cations previously prepared by phosphenium ion insertion into $\mathrm{P}_{4}$. The molecular structure of 3a is shown in Fig. 3, while those of $\mathbf{3 b}$ and $\mathbf{3} \mathbf{c}$ are presented in the ESI (Fig. S40 and S41 ). ${ }^{13}$ The structural parameters of the BIAN ligand are similar to those of 2 (vide supra). The coordinating phosphorus atoms $\mathrm{P} 1, \mathrm{P} 2, \mathrm{P} 3$, and $\mathrm{P} 4$ form an almost planar arrangement (Co-P $=2.3442(1) \AA-2.3720(1) \AA$ for 3a). The coordinated $\mathrm{P}-\mathrm{P}$ bonds show a short-long-short pattern (3a: P1-P2 2.12969(2) Å, P2-P3 2.1576(2) A, P3-P4 2.1297(2) Å), which indicates a diene-like arrangement. Scheer's salts $\left[\mathrm{Li}\left(\mathrm{Et}_{2} \mathrm{O}\right)\right]\left[\mathrm{Cp} * \mathrm{Fe}\left(\eta^{4}-\mathrm{P}_{5} \mathrm{CH}_{2} \mathrm{SiMe}_{3}\right)\right],\left[\mathrm{Na}_{3}(\mathrm{dme})_{5}\right]\left[\left\{\mathrm{Cp} * \mathrm{Fe}\left(\eta^{4}-\mathrm{P}_{5}\right)\right\}_{2} \mathrm{~N}\right]$ and $\left[\mathrm{Li}_{2}(\mathrm{dme})_{6}\right]\left[\left\{\mathrm{Cp} * \mathrm{Fe}\left(\eta^{4}-\mathrm{P}_{5}\right)\right\}_{2} \mathrm{PH}\right]$ (vide supra, scheme 1c)

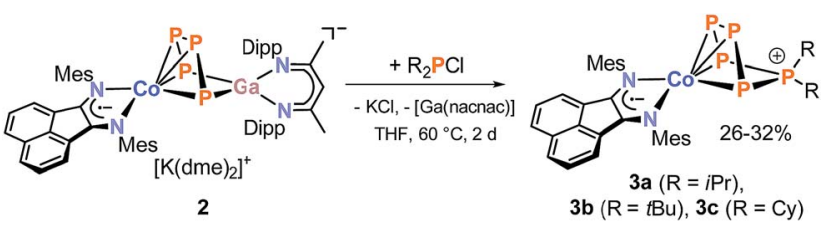

Scheme 3 Synthesis of $\left[\left({ }^{\text {Mes }} B I A N\right) C o\left(\eta^{4}-P_{5} R_{2}\right)\right][R=i \operatorname{Pr}(3 a), R=t B u$ (3b), $R=$ Cy (3c)].

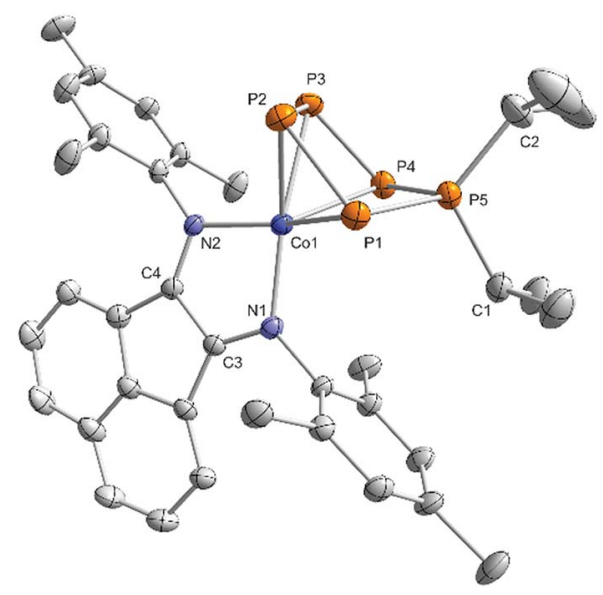

Fig. 3 Solid-state molecular structure of $\left[\left({ }^{\mathrm{Mes}} \mathrm{BIAN}\right) \mathrm{Co}\left(\eta^{4}-\mathrm{P}_{5} \mathrm{iPr} \mathrm{Pr}_{2}\right)\right](3 \mathrm{a})$; hydrogen atoms are omitted for clarity and thermal ellipsoids are drawn at the $40 \%$ probability level; selected bond lengths [Å] and angles [ ${ }^{\circ}$ ]: P1-P2 2.12969(2), P2-P3 2.1576(2), P3-P4 2.1297(2), P4-P5 2.1347(2), P5-P1 2.1506(1), P5-C1 1.8423(1), P5-C2 1.8458(1), Co1-P1 2.3720(1), Co1-P2 2.3442(1), Co1-P3 2.3447(2), Co1-P4 2.3595(2), Co1-N1 1.9104(1), Co1-N2 1.9480(1), N1-C3 1.32559(8), N2-C4 1.32069(8), C3-C4 1.4366(1); P1-P2-P3 103.926(5), P2-P3-P4 107.049(5), P3-P4-P5 98.104(6), P4-P5-P1 99.966(5), P5-P1-P2 100.689(5), C1-P5-C2 113.0644(5); bond distances and angles of derivatives $3 b$ and $c$ are presented in the ESI (see Fig. S40 and S41, ESI $\mid$ :.$^{13}$ 
display a similar envelope conformation of the monosubstituted cyclo- $\mathrm{P}_{5} \mathrm{R}$ units. ${ }^{10}$

The ${ }^{31} \mathrm{P}\left\{{ }^{1} \mathrm{H}\right\}$ NMR spectra of $3 a-c$ in $\mathrm{C}_{6} \mathrm{D}_{6}$ (Fig. 4 and S16, S21, and $\mathrm{S} 26$, ESI ${ }^{13}$ show very similar $\mathrm{AMM}^{\prime} \mathrm{XX}^{\prime}$ spin systems that are consistent with molecular structures observed in the solid state. The spectrum of 3a will be discussed in more detail here. The tetracoordinate, diorganosubstituted phosphorus nucleus $\left(\mathrm{P}_{\mathrm{A}}\right)$ resonates at higher frequency $(161.0 \mathrm{ppm}$ for $3 \mathrm{a})$ compared to the resonances of the metal-coordinated $\mathrm{P}$ atoms $(88.6 \mathrm{ppm}$ and $111.4 \mathrm{ppm}$, respectively, for $\mathbf{3 a}$ ). The $J_{\mathrm{PP}}$ coupling constants for the derivatives $\mathbf{3 a - c}$ were obtained by the iterative simulation of the ${ }^{31} \mathrm{P}\left\{{ }^{1} \mathrm{H}\right\}$ NMR spectra. ${ }^{13}$ The one-bond $\mathrm{P}-\mathrm{P}$ coupling constants of the coordinated $\mathrm{P}$ atoms $\left({ }^{1} \mathrm{JMM}_{\mathrm{MM}^{\prime}}=-380.6 \mathrm{~Hz}\right.$ and ${ }^{1} J_{\mathrm{MX}}=-414.2 \mathrm{~Hz}$ for $3 \mathrm{a}$ ) are comparable to those reported for $\left[\mathrm{Li}\left(\mathrm{Et}_{2} \mathrm{O}\right)\right]\left[\mathrm{Cp} * \mathrm{Fe}\left(\eta^{4}-\mathrm{P}_{5} \mathrm{CH}_{2} \mathrm{SiMe}_{3}\right)\right]\left({ }^{1} \mathrm{JMM}_{\mathrm{MM}^{\prime}}=-409.7 \mathrm{~Hz},{ }^{1} J_{\mathrm{Mx}}=\right.$ $-382.6 \mathrm{~Hz})$, but the ${ }^{1} J_{\mathrm{AX}}$ coupling constant $(-392.9 \mathrm{~Hz})$ is substantially larger $\left(-275.3 \mathrm{~Hz}\right.$ for $\left[\mathrm{Li}\left(\mathrm{Et}_{2} \mathrm{O}\right)\right]\left[\mathrm{Cp} * \mathrm{Fe}\left(\eta^{4}-\mathrm{P}_{5} \mathrm{CH}_{2}\right.\right.$ $\left.\left.\mathrm{SiMe}_{3}\right)\right] .{ }^{10}$ The values of the ${ }^{2} J_{\mathrm{PP}}\left({ }^{2} J_{\mathrm{MX}^{\prime}}=39.9 \mathrm{~Hz},{ }^{2} J_{\mathrm{AM}}=10.4 \mathrm{~Hz}\right.$, and ${ }^{2} J_{\mathrm{Xx}^{\prime}}=9.2 \mathrm{~Hz}$ for $3 \mathrm{a}$ ) are in the usual range.

In order to gain more insight in the mechanism of formation of the diorganopentaphosphido ligands in $\mathbf{3 a - c}$, we studied the reactions of 2 with $\mathrm{R}_{2} \mathrm{PCl}\left(\mathrm{R}=t \mathrm{Bu}\right.$ and iPr) by ${ }^{31} \mathrm{P}\left\{{ }^{1} \mathrm{H}\right\}$ NMR spectroscopy. While we did not detect any intermediate in the reaction with $t \mathrm{Bu}_{2} \mathrm{PCl}$, we observed two intermediate species in case of $\mathrm{iPr}_{2} \mathrm{PCl}$ (Fig. 5). The starting materials are consumed within ten minutes, while two similar ABCDE spin systems arise that are presumably assigned to the two intermediates Int-A and Int-B. Monitoring the reaction by ${ }^{31} \mathrm{P}\left\{{ }^{1} \mathrm{H}\right\}$ VT NMR spectroscopy initially shows the exclusive formation of intermediate Int-A at $-30{ }^{\circ} \mathrm{C}$. Upon warming the reaction mixture above $0{ }^{\circ} \mathrm{C}$, the signals of Int-B arise in the ${ }^{31} \mathrm{P}\left\{{ }^{1} \mathrm{H}\right\}$ NMR spectra. According to ${ }^{31} \mathrm{P}\left\{{ }^{1} \mathrm{H}\right\}$ NMR integration, Int-A and Int-B are present in a $4: 1$ ratio at room temperature independent of the reaction time (see Fig. S36, ESI $\$$ ). ${ }^{13}$ Given the fairly similar ${ }^{31} \mathrm{P}$ NMR patterns, it seems probable that Int-A and Int-B are constitutional isomers.

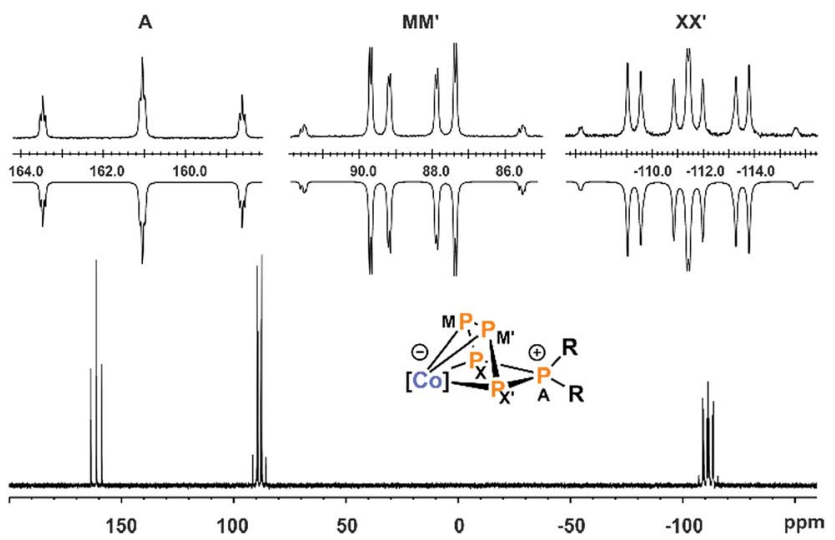

Fig. $4{ }^{31} \mathrm{P}\left\{{ }^{1} \mathrm{H}\right\}$ NMR spectrum of compound 3 a with nuclei assigned to $\mathrm{AMM}^{\prime} \mathrm{X} \mathrm{X}^{\prime}$ spin system; insets: extended signals (upwards) and simulations (downwards); $\delta\left(\mathrm{P}_{\mathrm{A}}\right)=161.0 \mathrm{ppm}, \delta\left(\mathrm{P}_{\mathrm{MM}^{\prime}}\right)=88.6 \mathrm{ppm}, \delta\left(\mathrm{P}_{\mathrm{XX}^{\prime}}\right)=$ -111.4 ppm, ${ }^{1} J_{A X}={ }^{1} J_{A X^{\prime}}=-392.9 \mathrm{~Hz},{ }^{1} J_{M M^{\prime}}=-380.6 \mathrm{~Hz},{ }^{1} J_{M X}={ }^{1} J_{M^{\prime} X^{\prime}}$ $=-414.2 \mathrm{~Hz},{ }^{2} J_{M^{\prime}}={ }^{2} J_{M^{\prime} X}=39.9 \mathrm{~Hz},{ }^{2} J_{A M}={ }^{2} J_{A^{\prime}}=10.4 \mathrm{~Hz},{ }^{2} J_{X^{\prime}}=$ $9.2 \mathrm{~Hz}$; the spectra of $3 \mathrm{~b}$ and c are very similar (see Fig. S21 and S26, $\mathrm{ESI}+)^{13}[\mathrm{Co}]=\left({ }^{\mathrm{Mes}} \mathrm{BIAN}\right) \mathrm{Co}$.

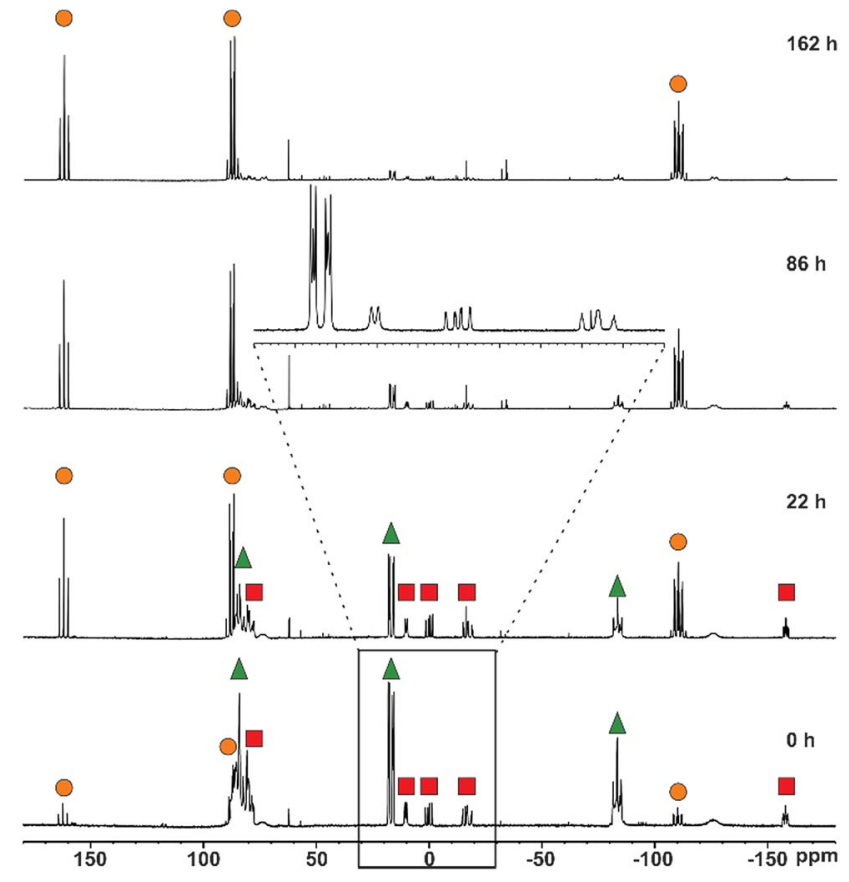

Fig. $5{ }^{31} \mathrm{P}\left\{{ }^{1} \mathrm{H}\right\}$ NMR monitoring of the reaction of 2 dissolved in THF$d_{8}$ with $\mathrm{iPr}_{2} \mathrm{PCl}$ in a 1:1 ratio at room temperature over seven days; resonances marked with are assigned to product [ $\left({ }^{\text {Mes }} \mathrm{BIAN}\right) \mathrm{Co}\left(\eta^{4}\right.$ $\left.\mathrm{P}_{5} \mathrm{Pr}_{2}\right)$ ] (3a) whereas those marked with $\Delta$ (Int-A) and $\square$ (Int-B) are assigned to intermediates; inset: section from $25 \mathrm{ppm}$ to $-25 \mathrm{ppm}$.

It is difficult to determine the precise molecular structures of Int-A and Int-B only from ${ }^{31} \mathrm{P}$ NMR investigation, but fortunately one of the intermediates crystallized from the reaction mixture and was characterized as $\left[\left({ }^{\mathrm{Mes}} \mathrm{BIAN}\right) \mathrm{Co}\left(\mu-\eta^{4}: \eta^{2}-\mathrm{P}_{5} \mathrm{iPr}_{2}\right) \mathrm{Ga}(\right.$ nacnac)] (4, Fig. 6). ${ }^{13}$ The ${ }^{31} \mathrm{P}\left\{{ }^{1} \mathrm{H}\right\}$ NMR spectrum of crystalline 4 in $\mathrm{C}_{6} \mathrm{D}_{6}$ recorded at room temperature after $10 \mathrm{~min}$ showed two sets of resonances which were identified as Int-A and Int-B in the same ratio as observed in the reaction mixture. Based on our calculated ${ }^{31} \mathrm{P}$ NMR chemical shieldings of $\mathbf{4}$, it seems plausible that intermediate Int-A can be assigned to $\mathbf{4}$ (see the ESI details). ${ }^{\mathbf{1 3}}$ Solid $\mathbf{4}$, when stored under an inert atmosphere, is stable for several weeks without decomposition, but it irreversibly converts to $3 \mathrm{a}$ when dissolved in $\mathrm{C}_{6} \mathrm{D}_{6}$ at ambient temperature over the course of five days as indicated by ${ }^{31} \mathrm{P}\left\{{ }^{1} \mathrm{H}\right\}$ NMR monitoring.

Based on these data, a mechanism of formation can be proposed for 3a (Scheme 4), which involves a pre-equilibrium between Int-A and Int-B. The latter species slowly converts into 3a by dissociation of [ $\mathrm{Ga}($ nacnac $)]$; this process appears to be irreversible.

The molecular structure of 4 confirms that $\mathrm{P}-\mathrm{P}$ bond formation has already occurred in this intermediate (Fig. 6). The structure is in line with the ${ }^{31} \mathrm{P}\left\{{ }^{1} \mathrm{H}\right\}$ NMR data (ABCDE spin system, vide infra) and shows an almost planar $\mathrm{P}_{5}$ chain which coordinates to cobalt via the four unsubstituted P atoms (P1-P2 $=2.122(1) \AA$, P2-P3 = 2.159(2) $\AA$, and P3-P4 = 2.164(1) $\mathrm{A})$. The $\mathrm{PiPr}_{2}$ unit adopts the terminal position (P4-P5 2.239(1) Å) and does not show close contacts to cobalt or gallium. The $[\mathrm{Ga}$ (nacnac) $]$ moiety is $\eta^{2}$-coordinated to the 1,4 -positions of the 


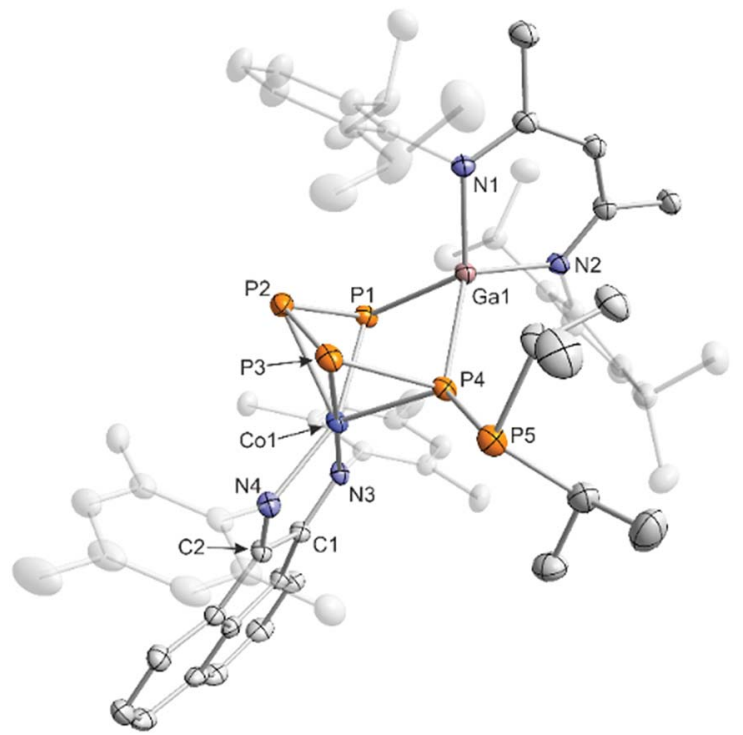

Fig. 6 Solid-state molecular structure of [( $\left.{ }^{\mathrm{Mes}} \mathrm{BIAN}\right) \mathrm{Co}\left(\mu-\eta^{4}: \eta^{2}-\mathrm{P}_{5} \mathrm{iPr} \mathrm{Pr}_{2}\right)$ $\mathrm{Ga}($ nacnac)] (4); hydrogen atoms are omitted for clarity and thermal ellipsoids are drawn at the $40 \%$ probability level; selected bond lengths $[\AA \AA]$ and angles $\left[{ }^{\circ}\right]$ : P1-P2 2.122(1), P2-P3 2.159(2), P3-P4 2.164(1), P4-P5 2.239(1), P1-Ga1 2.3320(9), P4-Ga1 2.418(1), Ga1-N1 1.992(3), Ga1N2 1.974(3), Co1-P1 2.348(2), Co1-P2 2.37(1), Co1-P3 2.306(1), Co1P4 2.353(1), Co1-N3 1.919(3), Co1-N4 1.963(3), C1-N3 1.335(4), C2N4 1.323(4), C1-C2 1.422(5), P1-P2-P3 103.59(5); P2-P3-P4 102.46(5), P3-P4-P5 93.59(5), P5-P4-Ga1 133.22(5), P1-Ga1-P5 82.28(3), Ga1-P1-P2 97.13(4).

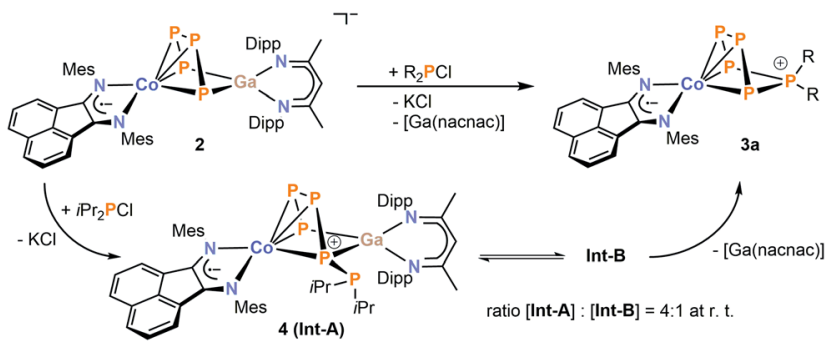

Scheme 4 Proposed mechanism of the condensation of $\mathrm{iPr}_{2} \mathrm{PCl}$ with 2 leading to product $3 a .{ }^{31} \mathrm{P}\left\{{ }^{1} \mathrm{H}\right\}$ NMR monitoring revealed two intermediates Int-A and Int-B in a 4:1 integral ratio at room temperature.

$\mathrm{P}_{5}$ chain $(\mathrm{P} 1-\mathrm{Ga} 1=2.3320(9) \AA, \mathrm{P} 4-\mathrm{Ga} 1=2.418(1) \AA)$ and the $\mathrm{C}-\mathrm{N}$ and $\mathrm{C}-\mathrm{C}$ bond lengths of the BIAN moiety are again comparable to 2 and $\mathbf{3 a - c}$, suggesting that the ligand is present in its radical monoanionic form.

Dialkylchlorophosphanes smoothly reacted with 2 to form a pentaphosphido framework, however, mono- and diarylchlorophosphanes gave intractable products. By contrast, $t \mathrm{BuPCl}_{2}$ (Scheme 5$)$ readily affords $t \mathrm{Bu}$-substituted [( $\left.{ }^{\mathrm{Mes}} \mathrm{BIAN}\right)$ $\mathrm{Co}\left(\mu-\eta^{4}: \eta^{1}-\mathrm{P}_{5} t \mathrm{Bu}\right) \mathrm{GaCl}($ nacnac) $\left.)\right](5)$ as the sole P-containing species detected by ${ }^{31} \mathrm{P}\left\{{ }^{1} \mathrm{H}\right\}$ NMR. An unidentified paramagnetic by-product was detected in the ${ }^{1} \mathrm{H}$ NMR spectrum of the crude reaction mixture. This undesired species can be completely removed by several recrystallization steps from toluene. This work-up procedure is the reason for the relatively low yield (6\%) for the spectroscopically and analytically pure

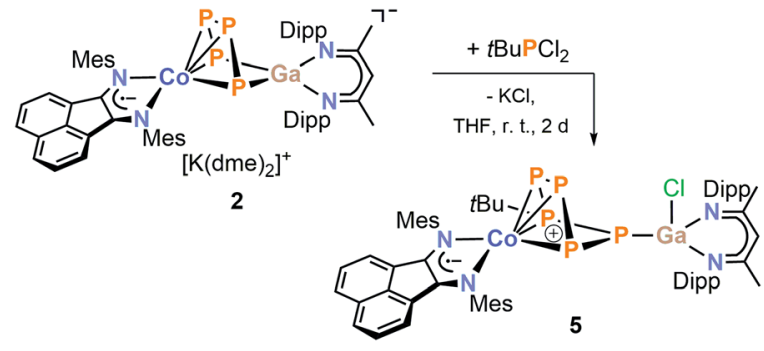

Scheme 5 Synthesis of $\left[\left({ }^{\text {Mes }} \mathrm{BIAN}\right) \mathrm{Co}\left(\mu-\eta^{4}: \eta^{1}-\mathrm{P}_{5} \mathrm{tBu}\right) \mathrm{GaCl}(\right.$ nacnac) $)$ (5).

isolated compound $\mathbf{5}$. The synthesis of $\mathbf{5}$ nevertheless is remarkable because it shows that $\mathrm{P}-\mathrm{P}$ condensations also occur with monoalkyldichlorophanes. The molecular structure of $\mathbf{5}$ determined by single-crystal XRD (Fig. 7) features an $\eta^{4}: \eta^{1}$-coordinated cyclo- $\mathrm{P}_{5} t \mathrm{Bu}$ ligand similar to the dialkylsubstituted ligands in 3a-c. The phosphorus atoms P2, P3, P4, and $\mathrm{P} 5$ coordinated to cobalt form an almost planar arrangement (Co-P $=2.33156(7) \AA-2.37439(6) \AA)$. Notably, the P atom at the tip of the cyclo- $\mathrm{P}_{5}$ envelope is coordinated to the gallium atom of $\mathrm{GaCl}\left(\right.$ nacnac) (P1-Ga1-P5 82.28(3) ${ }^{\circ}$, Ga1-P1-P5 $115.834(2)^{\circ}$, and Ga1-P1-P2 112.634(2) $\left.)^{\circ}\right)$. The structural parameters of the BIAN ligand are close to 2 and $3 \mathbf{a}-\mathbf{c}$ (vide supra). The $\mathrm{P}-\mathrm{P}$ bond distances (P1-P5 $=2.14148(6) \AA$, $\mathrm{P} 2-\mathrm{P} 3=$ $2.14129(5) \AA, \mathrm{P} 3-\mathrm{P} 4=2.13102(7) \AA$, and $\mathrm{P} 4-\mathrm{P} 5=2.13310(5) \AA)$ are in a very close range except for the P1-P2 bond (2.19903(6) $\AA$ ).

Compound 5 gives rise to an ABEMX spin system in the ${ }^{31} \mathrm{P}\left\{{ }^{1} \mathrm{H}\right\}$ NMR spectrum, which was simulated using an iterative

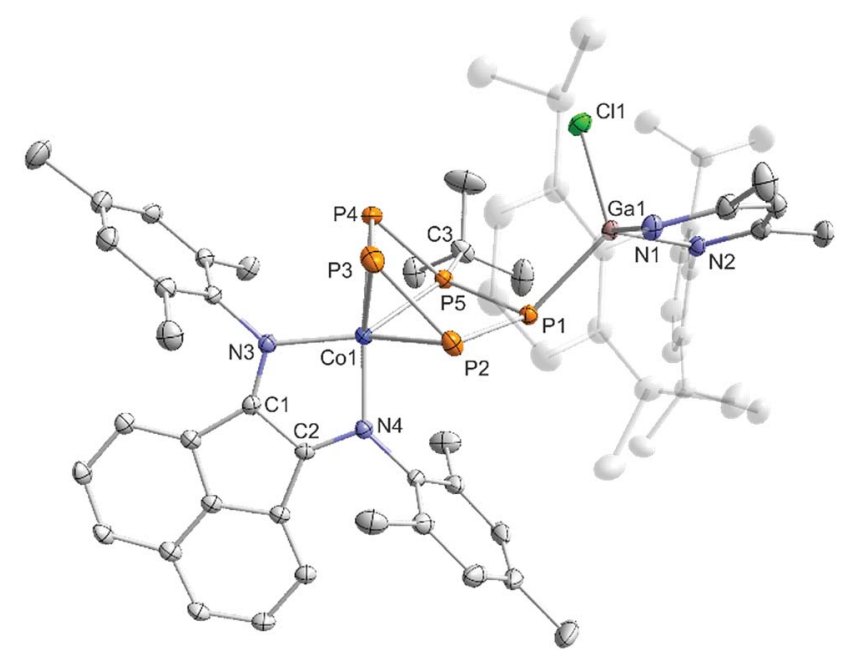

Fig. 7 Solid-state molecular structure of [( $\left.{ }^{\text {Mes }} B I A N\right) C o\left(\mu-\eta^{4}: \eta^{1}-P_{5} t B u\right)$ $\mathrm{GaCl}($ nacnac)] (5); hydrogen atoms are omitted for clarity and thermal ellipsoids are drawn at the $40 \%$ probability level; selected bond lengths [Å] and angles $\left[^{\circ}\right]$ : P1-P2 2.19903(6), P2-P3 2.14129(5), P3-P4 2.13102(7), P4-P5 2.13310(5), P5-P1 2.14148(6), P1-Ga1 2.34200(6), P5-C3 1.89094(6), Ga1-N1 1.94202(6), Ga1-N2 1.96271(5), Ga1-Cl1 2.20080(5), Co1-P2 2.33156(7), Co1-P3 2.33788(6), Co1-P4 2.37439(6), Co1-P5 2.23375(6), Co1-N3 1.95761(5), Co1-N4 1.90519(4), C1-N3 1.31832(3), C2-N4 1.32622(3), C1-C2 1.42740(3); P1-P2-P3 113.062(2), P2-P3-P4 103.661(2), P3-P4-P5 97.566(2), P4-P5-P1 118.046(2), P5-P1-P2 84.471(2), P4-P5-C3 112.065(2), P4-P5-C3 115.399(2), Ga1-P1-P5 115.834(2), Ga1-P1-P2 112.634(2). 

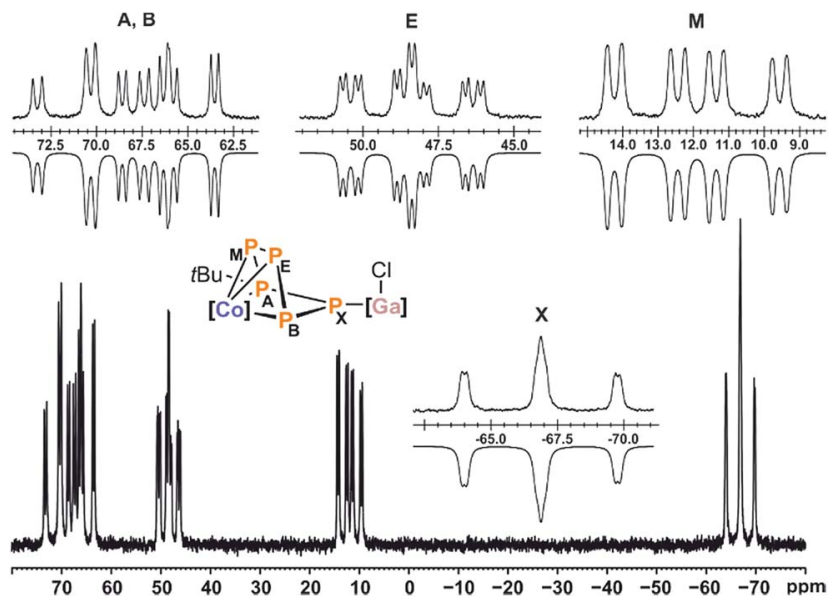

Fig. $8{ }^{31} \mathrm{P}\left\{{ }^{1} \mathrm{H}\right\}$ NMR spectrum of compound 5 at $-60{ }^{\circ} \mathrm{C}$ with nuclei assigned to $A B E M X$ spin system; insets: extended signals (upwards) and simulations (downwards); $\delta\left(\mathrm{P}_{\mathrm{A}}\right)=70.3 \mathrm{ppm}, \delta\left(\mathrm{P}_{\mathrm{B}}\right)=66.0 \mathrm{ppm}, \delta\left(\mathrm{P}_{\mathrm{E}}\right)=$ $48.4 \mathrm{ppm}, \delta\left(\mathrm{P}_{\mathrm{M}}\right)=12.0 \mathrm{ppm}, \delta\left(\mathrm{P}_{\mathrm{X}}\right)=-66.8 \mathrm{ppm},{ }^{1} \mathrm{~J}_{\mathrm{AM}}=-466.3 \mathrm{~Hz}$, ${ }^{1} J_{\mathrm{AX}}=-481.4 \mathrm{~Hz},{ }^{1} \mathrm{~J}_{\mathrm{BX}}=-455.1 \mathrm{ppm},{ }^{1} J_{\mathrm{BE}}=-367.0 \mathrm{~Hz},{ }^{1} J_{\mathrm{EM}}=$ $-291.6 \mathrm{~Hz},{ }^{2} J_{\mathrm{AE}}=81.8 \mathrm{~Hz},{ }^{2} J_{\mathrm{AB}}=8.2 \mathrm{~Hz},{ }^{2} J_{\mathrm{BM}}=67.7 \mathrm{~Hz},{ }^{2} J_{\mathrm{EX}}=$ $33.7 \mathrm{~Hz},{ }^{2} J_{\mathrm{MX}}=12.2 \mathrm{~Hz}$; [Co] $=\left({ }^{\mathrm{Mes}} \mathrm{BIAN}\right) \mathrm{Co},[\mathrm{Ga}]=($ nacnac $) \mathrm{Ga}$.

fitting procedure (Fig. 8). Based on the observed P-P couplings and an additional ${ }^{31} \mathrm{P}-{ }^{1} \mathrm{H}$ HMBC spectrum, the resonance at $70.3 \mathrm{ppm}\left(\mathrm{P}_{\mathrm{A}}\right)$ can be assigned to $t \mathrm{Bu}$-substituted phosphorus atom. At room temperature, this resonance is broad; hence, the simulation was carried out for the spectrum recorded at $-60{ }^{\circ} \mathrm{C}$. The resulting ${ }^{31} \mathrm{P}$ NMR data suggest that the signals at $12.0 \mathrm{ppm}$ $\left(\mathrm{P}_{\mathrm{M}}\right)$ and $-66.8 \mathrm{ppm}\left(\mathrm{P}_{\mathrm{X}}\right)$ can be assigned to the $\mathrm{P}$ atoms adjacent to the $t \mathrm{Bu}$-substituted $\mathrm{P}$ atom $\left(\mathrm{P}_{\mathrm{A}}\right.$, Fig. S34, ESI $\left.\$\right) .{ }^{13}$

\section{Conclusions}

The anionic cobalt-gallium tetraphosphido complex 2 is readily accessible by reaction of $\left[\mathrm{K}\left(\mathrm{Et}_{2} \mathrm{O}\right)\left\{\left({ }^{\mathrm{Mes}} \mathrm{BIAN}\right) \mathrm{Co}\left(\eta^{4}-1,5-\mathrm{cod}\right)\right\}\right]$ (1) with $\left[\mathrm{Ga}(\right.$ nacnac $\left.)\left(\eta^{2}-\mathrm{P}_{4}\right)\right]$. This unique heterobimetallic complex features an activated catena- $\mathrm{P}_{4}$ unit amenable to $\mathrm{P}-\mathrm{P}$ condensation reactions. Remarkably, 2 readily forms unprecedented organosubstituted pentaphosphido complexes 3a-c, 4, and 5 with $\mathrm{R}_{2} \mathrm{PCl}(\mathrm{R}=\mathrm{iPr}, t \mathrm{Bu}$, and $\mathrm{Cy})$ and $t \mathrm{BuPCl}_{2}$. Related metal-free $\left[\mathrm{P}_{5} \mathrm{R}_{2}\right]^{+},\left[\mathrm{P}_{6} \mathrm{R}_{4}\right]^{2+}$, and $\left[\mathrm{P}_{7} \mathrm{R}_{6}\right]^{2+}$ cations have been prepared by phosphenium cation insertion into $\mathrm{P}_{4} ;^{24-27}$ metal complexes with monosubstituted $\mathrm{P}_{n} \mathrm{R}$ ligands were accessed by reaction of nucleophiles, e.g. alkali metal alkyls, amides and phosphides, on pentaphosphaferrocene and related complexes. ${ }^{\mathbf{9}, \mathbf{1 0}}$ Notwithstanding these previous examples, the results reported in this study show that P-P condensation reactions of anionic polyphosphido complexes and halophosphanes are a potentially powerful synthetic approach which can give rise to unusual new polyphosphorus species. NMR and single-crystal XRD experiments have revealed that $\mathrm{P}-\mathrm{P}$ bond formation is facile as shown by the formation of intermediate $\mathbf{4}$ characterized by X-ray crystallography. By contrast, the subsequent elimination of the [Ga(nacnac)] building block from 4 seems to be associated with a considerable barrier. The reaction properties of $\mathbf{3 a - c}$ and $\mathbf{5}$ are currently under investigation. Moreover, efforts are underway to extend and fine tune the $\mathrm{P}-\mathrm{P}$ condensation approach for the synthesis of further unprecedented polyphosphorus compounds.

\section{Conflicts of interest}

There are no conflicts to declare.

\section{Acknowledgements}

We thank Dr Stefanie Gärtner (Central Analytical Services, University of Regensburg) for crystallographic assistance and Kerstin Rothermel (Gschwind group, University of Regensburg) for assistance with NMR measurements. Generous funding by the Deutsche Forschungsgemeinschaft (WE4621/3-1 and WO1496/7-1) and the Fonds der Chemischen Industrie (fellowship to T. M. Maier) is gratefully acknowledged.

\section{Notes and references}

1 (a) M. Caporali, L. Gonsalvi, A. Rossin and M. Peruzzini, Chem. Rev., 2010, 110, 4178; (b) M. Scheer, G. Balázs and A. Seitz, Chem. Rev., 2010, 110, 4236; (c) M. Peruzzini, L. Gonsalvi and A. Romerosa, Chem. Soc. Rev., 2005, 34, 1038; (d) N. A. Giffin and J. D. Masuda, Coord. Chem. Rev., 2011, 255, 1342.

2 B. M. Cossairt, N. A. Piro and C. C. Cummins, Chem. Rev., 2010, 110, 4164.

3 J. S. Figueroa and C. C. Cummins, Dalton Trans., 2006, 2161. 4 J. S. Figueroa and C. C. Cummins, J. Am. Chem. Soc., 2004, 126, 13916.

5 (a) N. A. Piro, J. S. Figueroa, J. T. McKellar and C. C. Cummins, Science, 2006, 313, 1276; (b) B. M. Cossairt and C. C. Cummins, Angew. Chem., Int. Ed., 2010, 49, 1595; (c) A. Velian and C. C. Cummins, Chem. Sci., 2012, 3, 1003.

6 B. M. Cossairt, M.-C. Diawara and C. C. Cummins, Science, 2009, 323, 602.

7 (a) J. S. Figueroa and C. C. Cummins, Angew. Chem., Int. Ed., 2004, 43, 984; (b) D. Tofan, B. M. Cossairt and C. C. Cummins, Inorg. Chem., 2011, 50, 12349.

8 (a) P. Barbaro, C. Bazzicalupi, M. Peruzzini, S. Seniori Costantini and P. Stoppioni, Angew. Chem., Int. Ed., 2012, 51, 8628; (b) P. Barbaro, M. Di Vaira, M. Peruzzini, S. Seniori Costantini and P. Stoppioni, Chem. - Eur. J., 2007, 13, 6682; (c) M. Di Vaira, P. Frediani, S. S. Costantini, M. Peruzzini and P. Stoppioni, Dalton Trans., 2005, 2234; (d) M. Di Vaira, M. Peruzzini, S. Seniori Costantini and P. Stoppioni, J. Organomet. Chem., 2006, 691, 3931; (e) P. Barbaro, M. Peruzzini, J. A. Ramirez and F. Vizza, Organometallics, 1999, 18, 4237; $(f)$ P. Barbaro, A. Ienco, C. Mealli, M. Peruzzini, O. J. Scherer, G. Schmitt, F. Vizza and G. Wolmershäuser, Chem.-Eur. J., 2003, 9, 5196; $(g)$ M. Peruzzini, J. A. Ramirez and F. Vizza, Angew. Chem., Int. Ed., 1998, 37, 2255.

9 (a) R. F. Winter and W. E. Geiger, Organometallics, 1999, 18, 1827; (b) M. V. Butovskiy, G. Balázs, M. Bodensteiner, E. V. Peresypkina, A. V. Virovets, J. Sutter and M. Scheer, 
Angew. Chem., Int. Ed., 2013, 52, 2972; (c) E. Mädl, G. Balázs, E. V. Peresypkina and M. Scheer, Angew. Chem., Int. Ed., 2016, 55, 7702.

10 (a) E. Mädl, M. V. Butovskii, G. Balázs, E. V. Peresypkina, A. V. Virovets, M. Seidl and M. Scheer, Angew. Chem., Int. Ed., 2014, 53, 7643; (b) E. Mädl, G. Balázs, E. V. Peresypkina and M. Scheer, Angew. Chem., Int. Ed., 2016, 55, 7702.

11 A. E. Seitz, M. Eckhardt, A. Erlebach, E. V. Peresypkina, M. Sierka and M. Scheer, J. Am. Chem. Soc., 2016, 138, 10433. 12 S. Pelties, T. Maier, D. Herrmann, B. d. Bruin, C. Rebreyend, S. Gärtner, I. G. Shenderovich and R. Wolf, Chem. - Eur. J., 2017, 23, 6094.

13 See the ESIt for further details.

14 (a) G. Prabusankar, A. Doddi, C. Gemel, M. Winter and

R. A. Fischer, Inorg. Chem., 2010, 49, 7976; (b) F. Hennersdorf, J. Frötschel and J. J. Weigand, J. Am. Chem. Soc., 2017, 139, 14592; (c) F. Hennersdorf and J. J. Weigand, Angew. Chem., Int. Ed., 2017, 56, 7858.

15 (a) S. Alvarez, Dalton Trans., 2013, 42, 8617; (b) B. Cordero, V. Gómez, A. E. Platero-Prats, M. Revés, J. Echeverría, E. Cremades, F. Barragán and S. Alvarez, Dalton Trans., 2008, 2832.

16 O. J. Scherer, M. Swarowsky, H. Swarowsky and G. Wolmershäuser, Angew. Chem., Int. Ed. Engl., 1988, 27, 694.
17 Y. Xiong, S. Yao, E. Bill and M. Driess, Inorg. Chem., 2009, 8, 7522.

18 T. Li, N. Arleth, M. T. Gamer, R. Köppe, T. Augenstein, F. Dielmann, M. Scheer, S. N. Konchenko and P. W. Roesky, Inorg. Chem., 2013, 52, 14231.

19 O. J. Scherer, T. Hilt and G. Wolmershäuser, Organometallics, 1998, 17, 4110.

20 V. A. Miluykov, O. G. Sinyashin, P. Lönnecke and E. HeyHawkins, Mendeleev Commun., 2003, 13, 212.

21 M. D. Walter, J. Grunenberg and P. S. White, Chem. Sci., 2011, 2, 2120.

22 W. W. Seidel, O. T. Summerscales, B. O. Patrick and M. D. Fryzuk, Angew. Chem., Int. Ed., 2009, 48, 115.

23 M. Baudler, Y. Aktalay, K.-F. Tebbe and T. Heinlein, Angew. Chem., Int. Ed. Engl., 1981, 20, 967.

24 I. Krossing and I. Raabe, Angew. Chem., Int. Ed., 2001, 40, 4406.

25 M. H. Holthausen, S. K. Surmiak, P. Jerabek, G. Frenking and J. J. Weigand, Angew. Chem., Int. Ed., 2013, 52, 11078.

26 M. H. Holthausen, A. Hepp and J. J. Weigand, Chem. - Eur. J., 2013, 19, 9895.

27 M. H. Holthausen, K.-O. Feldmann, S. Schulz, A. Hepp and J. J. Weigand, Inorg. Chem., 2012, 51, 3374. 